UDC 331; DOI 10.18551/rjoas.2022-01.01

\title{
THE ASSESSMENT OF EMPLOYEE PERFORMANCE BASED ON CULTURE AND LEADERSHIP ASPECTS IN THE DIGITAL ERA OF ORGANIZATIONAL LEARNING
}

\author{
Muniroh*, Hamidah, Abdullah Thamrin \\ University of Negeri Jakarta, Indonesia \\ *E-mail: munirohuni@gmail.com
}

\begin{abstract}
Nowadays a company providing services to the public always focuses on optimizing services from human resources and available machines or tools, especially in the digital era. To be able to achieve a high level of performance, the Company must be able to increase customer satisfaction, achieve efficiency, and effectiveness as well high organizational performance. This study aims to build a conceptual model and empirical model by analyzing and proving the influence of leadership and cultural aspects in the digital era, especially in the aspect of organizational learning, as well as providing innovation to employee performance at PT. Telkom Digital and Next Business Department. This research method uses the SEM PLS model which is one of the reliable methods in assessing the value of the influence between variables. The locus of research is at PT. Telkom Digital and Next Business Department always have various creative ideas in scientific development in the field of digitalization. The results and novelties obtained from this study are the analysis of the assessment of employee performance based on culture and leadership aspects in the era of digital organizational learning. The transformation requires that executives must change what they expect from HR and their behavior towards HR staff and expand their role in the organization by having prerequisite skills, becoming strategic partners, strategic knowledge, becoming administrative experts, with efforts to maintain the new transformation according to $\mathrm{HR}$ functions. and develop new competencies to meet changing roles and responsibilities.
\end{abstract}

\section{KEY WORDS}

Employee performance, innovation, leadership, culture, organizational learning.

The work culture regarding responsibility in an organizational regulation that is in the work environment of the retail department store service business is due to the lack of communication between units within the organization, cooperation between employees in each organizational unit, responsibilities that produce goals from work results, while compensation is not following the expected performance. carried out, and employee performance measurement is rarely carried out in the organization, as well as employee promotions that are not following the competencies possessed by the employee, and the problems experienced by subordinates are very less noticed by superiors, as well as a less solid commitment between teams so that all employees in any field are lacking able as a marketer. Digital culture with various obstacles faced such as poor ICT infrastructure, scarcity of IT policies, lack of awareness of government officials, unacceptable system, lack of coordination, low literacy rate, lack of IT training, high costs, lower internet obligations. access, lack of funds, poor salary structure, wrong assignments and blocked posts, widespread corruption, lack of attention in complaint centers, law and order situation, complexity in obtaining required services, and lack of information.

To support the vision and mission of PT. Telkom Digital and Next Business Department, it is necessary to increase HR performance. Employees who have good performance will be able to carry out their work under the duties and functions that have been assigned to them, the role of employees is very important in maintaining job stability to improve work quality through the potential of each employee by having high innovation and creativity, establishing good communication with internal and external parties, as well as maintaining the good name of the company. 
Table 1 - Number of Employees of PT. Telkom 2016 - 2018

\begin{tabular}{llll}
\hline $\mathrm{n} / \mathrm{n}$ & 2018 & 2017 & 2016 \\
\hline Telkom employees & 12.726 & 13,956 & 14.933 \\
\hline Subsidiary Employees & 11.306 & 10.109 & 8,943 \\
\hline TOTAL & 24,071 & 24,065 & 23,876 \\
\hline
\end{tabular}

Source: Telkom, 2018.

With the rapid growth of environmental changes, managers and modern organizational leaders have very complex problems today. With the management of the organization in the past and has lost its effectiveness as a growing organization, creating new ideas, the organization makes changes in managing management with learning methods and adapting to change. One very modern idea today is called a learning organization with an emphasis and must continuously adapt to any changes.

There are various problems from several references that researchers have conveyed and there are several problems that occur at PT. The Telkom Digital and Next Business Departments include: There is still a lack of human resources and management talent needed to support the organization, and not all leaders have the same talent related to digital leadership, due to different experiences for each division. Lack of readiness in understanding the digital culture that must be improved and applied at the senior level, especially at the working period of 15 years and above, lack of operational costs from various fields in increasing innovation in making new start-up projects, and lack of time in handling new startup projects,

In addition to some of the problems above, in terms of structure within the organization of PT. Telkom Digital and Next Business Department face different challenges because it is part of PT. Telkom Digital and Next Business Department which is a State-Owned Enterprise (BUMN) which is supposed to comply with the company's regulations and implementation following Good Corporate Governance (GCG). PT. Telkom Group in providing services to the public always focuses on optimizing human resource services, to achieve a high level of performance in increasing customer satisfaction, efficiency, and effectiveness as well as improving overall organizational performance.

\section{MATERIALS AND METHODS OF RESEARCH}

The term performance is often associated with employee performance to support the achievement of organizational performance levels and is related to the final product of a series of processes that are passed in stages, namely the level of achievement of results to realize company goals, which are influenced by many factors, both internal and external.

Performance is the ability of employees to achieve goals, both personal and organizational interests, by using resources efficiently and effectively. The factors that affect performance are:

- Personal Factor, addressed by the level of skills, competencies possessed motivation and individual commitment;

- Leadership Factor, determined by the quality of encouragement, guidance, and support by managers and team leaders;

- Team factors, indicated by the quality of support provided by colleagues;

- System FactorsThis is indicated by the existence of a work system and facilities provided by the organization;

- Contextual/situational factors, indicated by high levels of pressure and changes in the internal and external environment.

Inadequate past leadership and higher capabilities need to be improved in, the 4.0 revolution era due to global influences, both macro, and micro which make business situations more complex in changes that are difficult to predict with faster changes. In the organization leadership traits and attitudes leaders to influence others are very decisive in achieving organizational goals. 
Today's corporate organizations are characterized by very rapid developments related to communication and information resources as the information age. Digital culture is a change in corporate culture in a successful transformation; most companies in today's industry have an established (established) culture that values a single, focused skill that can be developed over decades of working in the same environment.

There are four important things related to the characteristics of organizational culture including:

- Shared concept: Cultureorganization consists of beliefs and values that are shared among a group of people;

- Learning over time: This is passed on to new employees through the socialization process;

- Influence our behavior at work;

- Results impact on multiple levels.

Learning organizations are constantly changing, every organization must learn from the past, both from competitors, and experts to stay competitive. Learning is a key ingredient in growth, becoming more effective and socially responsible, and maintaining a business value proposition. Whereas organizational learning as assessment criteria includes:

- Commitment for learning: Learning must be seen as a deeply rooted value for the company and must be deeply rooted in the culture of the organization. This value too affect how actively its members will act with a learning attitude;

- Shared vision: Management must share the company's vision for future development and further provide learning direction for making commitments to the company and achieving goals;

- Open mind: It deals with creative thinking beyond the rules and levels of belief and assumptions to actively challenge existing conventions that have been held for the long term;

- Knowledge sharing within the organization;

- The overall confidence of the organization can be increased by learning and diffusion of knowledge across departments.

Globalization in developing countries is increasingly felt in both the private sector and the government sector. This pressure makes companies increasingly improve in various changes called innovation, all fields of $R \& D$, software, design, educational engineering, marketing, and management are increasingly taking an important role in the production of goods and services. In addition, the development of international standards dominates international trade and global value chains. Therefore, the competitiveness of companies and countries depends on the company's ability to innovate and orient towards technology and information.

This research was conducted in PT. Telkom Digital and Next Business Department. The address is Menara Multimedia Lt. 15. Jalan Kebon Sirih No. 12 Jakarta. The research was conducted from 26 April 2018untilby until April 2021. This research includes several stages, starting with observations in the form of consultations with the leadership of PT. Telkom Digital and Next Business Department and continued with Pre survey to find out the problems of the research topic which will be discussed further by distributing questionnaires to conduct a series of instrument tests both validity and reliability and finally by distributing questionnaires to all 160 respondents for groups IV, V and VI on staff officer.

To be able to find answers in the formulation of research problems to achieve research objectives, this research was designed using quantitative research methods. Quantitative data were collected directly from respondents through a questionnaire instrument which is closely related to the variables in the research where $X 1$ is Digital Leadership (KD), $X 2$ Digital Culture (BD), X3 Organizational Learning (PO), X4 Innovation (IN), and Y1 Employee Performance (KK). Quantitative research shows the use of quantitative data in analyzing the phenomena that occur. Quantitative data used is data on a nominal and interval scale, where the answers of respondents in the form of qualitative are converted into quantitative form. 
Structural Equation Modeling Analysis (SEM) is used to analyze the relationship between variables and measure the influence of one variable on another variable. There are two types of SEM, namely Convariance Base SEM (CB-SEM) and Variance Base SEM (VBSEM), CB-SEM is used to confirm or reject a theory, through the explanation of theoretical models through explanatory research. VB-SEM focuses on the dependent variable variance when describing the model(Hair, 2014) Based on what Hair said regarding the Rule of thumb (Hair, 2014) then the CB-Sem or Partial Least Square SEM method will be used in the next analysis stage. The purpose of CB-SEM or Partial Least Square (PLS) is for prediction, therefore it focuses more on data with limited estimation procedures. PLS-SEM consists of two sub-models, namely the Outer model/measurement model and the Inner Model.

This study uses five variables the data comes from observational employees of PT. Telkom Digital and Next Business Department in Jakarta and Bandung areas. By using a structured questionnaire designed and distributed to a representative sample of the population. By answering every question asked simultaneously. The independent variables or exogenous variables consist of Digital Leadership, Digital Culture, Organizational Learning, Innovation as a moderating variable, Employee performance as an endogenous variable, a constellation of research is developed into a research design using SEM PLS on a first-order unidimensional construct, where the direction of the relationship is reflective between a latent variable with indicators where all relationships are recursive.

Populations are dynamic beings formed by the intrinsic relationships of their two members with other populations which together produce their existence and make meaningful ordinary conclusions possible. In this study, the population is all employees who work at PT. Telkom Digital and Next Business Department. The area of Jakarta and Bandung is 306 employees, while the samples taken are 160 employees from all employees at PT. Telkom Digital and Next Business Department. Consisting of staff officer level as follows:

Table 2 - Permanent Employee Population

\begin{tabular}{cccc}
\hline No & Level Name & Description & Number of Permanent Employees (Person) \\
\hline 1 & Level IV & Officer staff & 107 \\
\hline 2 & Level V & Officer staff & 115 \\
\hline 3 & Level VI & Officer staff & 84 \\
\hline & Amount & & 306 People \\
\hline
\end{tabular}

$$
\eta=\frac{N}{1+N \cdot e^{2}}=160
$$
below:

So that the samples obtained for each level of company staff are as shown in the table

Table 3 - Permanent Employee Population

\begin{tabular}{|c|c|c|c|c|c|}
\hline No & Level Name & Description & Presentation & Sub sample & N Sample \\
\hline 1 & Level IV & $\begin{array}{c}\text { Officer staff } \\
\text { (Over 1 Year) }\end{array}$ & 107 & $107 / 306 \times 160$ & 56 \\
\hline 2 & Level V & $\begin{array}{c}\text { Officer staff } \\
\text { (Above 1 Year) }\end{array}$ & 115 & $115 / 306 \times 160$ & 60 \\
\hline 3 & Level VI & $\begin{array}{c}\text { Officer staff } \\
\text { (Under 1 Year) }\end{array}$ & 84 & $84 / 306 \times 160$ & 44 \\
\hline Amount & & & 306 & & 160 \\
\hline
\end{tabular}

The sample in this study is several populations, namely all employees of PT. Telkom Digital and Next Business Department Level IV, V, and VI staff officers' total of 160 people.

In this study, there are two types of data collected, namely secondary data and primary data. Secondary data obtained from PT. Telkom Digital and Next Business Department, both journals, articles, and literature as well as other relevant documents. While primary data was sourced from respondents, namely employees of PT. Telkom Digital and Next Business Department Level IV, V and VI. Variable data on Digital Leadership (X1), Digital Culture (X2), 
Organizational Learning (X3), Innovation (X4), and Employee Performance (Y1) were collected using measurement instruments developed through theoretical studies. Employee performance (Employee performance) is measured using three indicators consisting of Creativity achieved, Proving full ability, Effectiveness in work. To obtain an objective measurement, employee performance assessment is carried out through distributing questionnaires aimed at employees of PT. Telkom Digital and Next Business Department.

Convergent Validity aims to determine the validity of each relationship between the indicator and the construct or latent variable. In this study, the outer loading limit or loading factor of 0.70 will be used.

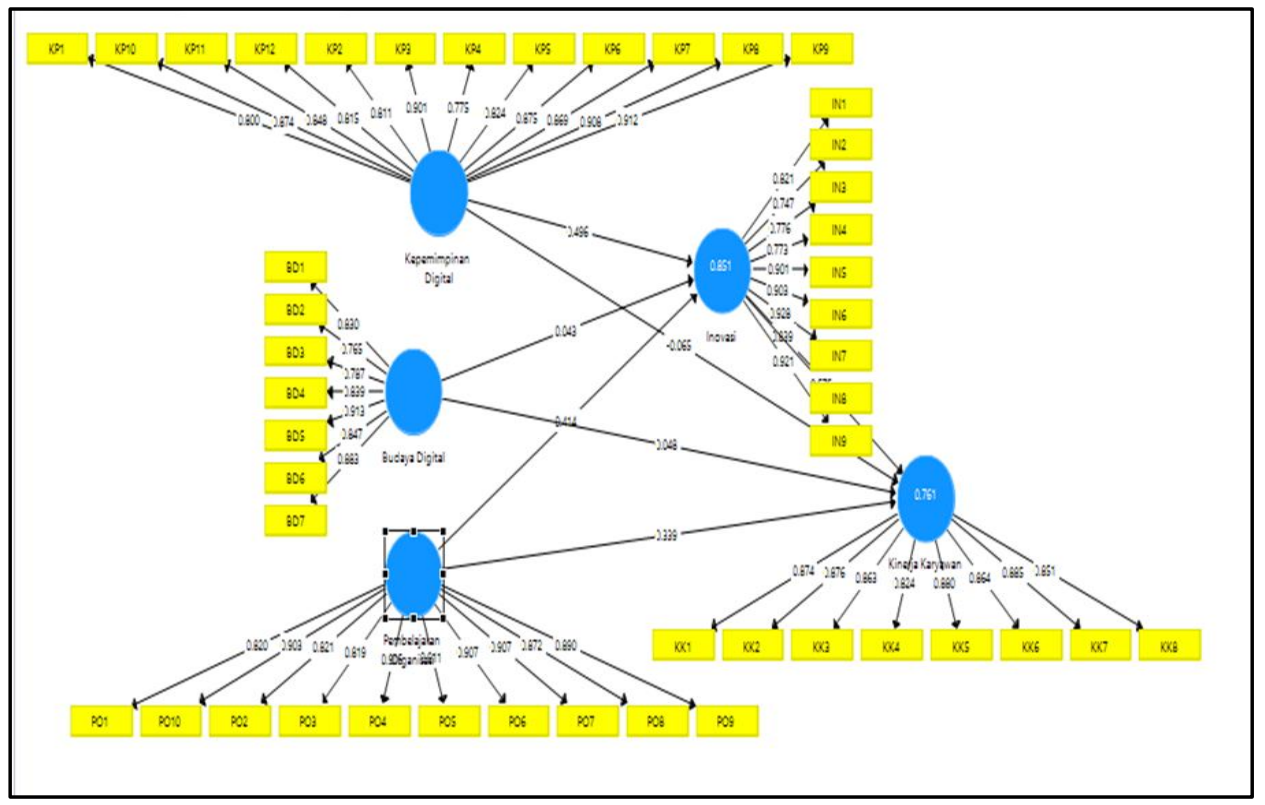

Figure 1 - Outer Model Results

Inner model measurement is intended to see the fit of the model and measure the direct and indirect effects. To get the results of the inner model analysis, the research model needs to be bootstrapped. The inner model analysis uses R square (goodness fit model), Path coefficient, and indirect effect.

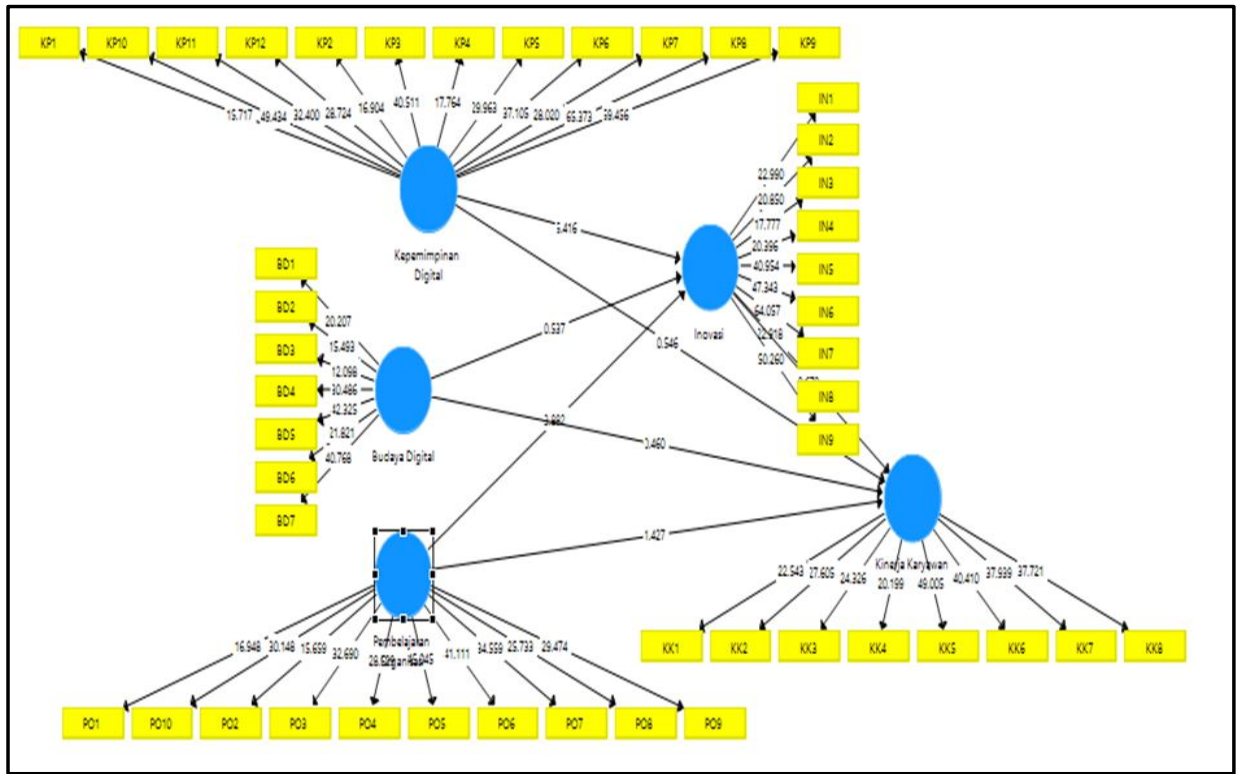

Figure 2 - Outer Model Results 


\section{RESULTS AND DISCUSSION}

From the calculation results above, it can be seen that the influence of Digital Leadership on innovation is the strongest, then followed by organizational learning on innovation, then Innovation on Employee Performance, Then organizational learning on employee performance and Digital Culture on Innovation, then Leadership on Employee Performance and the other Lastly, Digital Culture on Employee Performance.

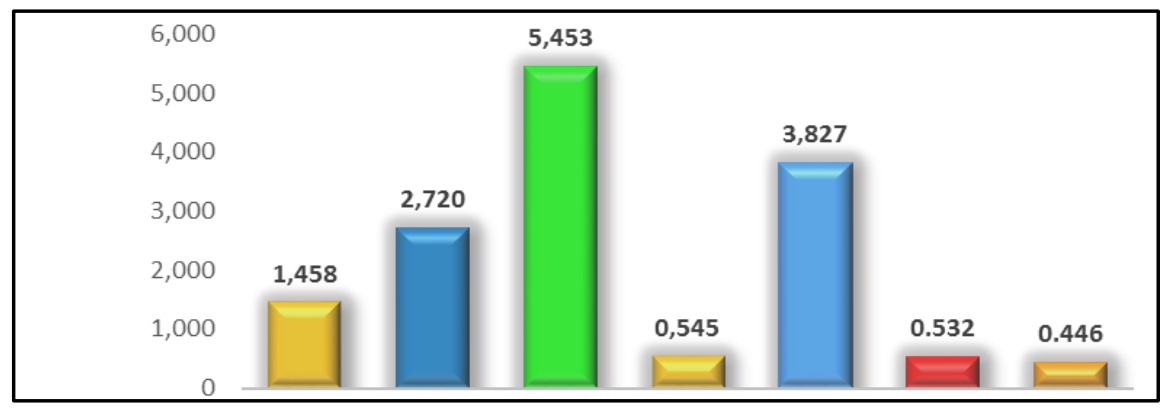

Figure 3 - Direct Effect Diagram between Variables

Table 4 - The Result of Employee Performance Variables

\begin{tabular}{ccc}
\hline Variable & Aspect & Result \\
\hline \multirow{2}{*}{ Employee performance } & Achieved creativity & Keep up the Good Work \\
\cline { 2 - 3 } & Proving ability & Concentrate Here \\
& Effectiveness at work & Possible Over Skill \\
\hline
\end{tabular}

From Table 4 above, it can be seen that the Creativity achieved is in Quadrant I (Keep up the Good Work) which means that the indicator is already very good and the focus is on the Proving ability indicator, which means that the indicator is the main priority that must be considered. so that it is further improved to become more and the indicators of Effectiveness at work are in Quadrant II which means that these indicators must be maintained consistently.

Table 5 - The Result of on Digital Leadership Variables

\begin{tabular}{lll}
\hline Variable & Aspect & Result \\
\hline Digital Leadership & Influence others & Possible Over Skill \\
\cline { 2 - 3 } & Have a vision for the future & Low Priority \\
\cline { 2 - 3 } & Communicate well internally & Keep up the Good Work \\
\cline { 2 - 3 } & Communicate well externally & Keep up the Good Work \\
\cline { 2 - 3 } & Technology leadership skills & Concentrate Here \\
\hline
\end{tabular}

The results of the second hypothesis analysis provide findings that Digital Culture does not have a direct positive effect on employee performance, this can be interpreted as a higher digital culture will lead to increased employee performance, lower digital culture will cause decreased employee performance.

From the results of the calculation of Structural Equation Modeling, it is empirically proven that the Digital Culture variable does not affect Employee Performance. It can be seen from the results of the study that Digital Culture has no direct effect on employee performance as seen from the P-Values of 0.656. $>0.05$. The results of this study are not in line with the research.

Table 6 - The Result of Digital Culture Variables

\begin{tabular}{ccc}
\hline Variable & Aspect & Result \\
\hline \multirow{3}{*}{ Digital Culture } & Application available & Low Priority \\
\cline { 2 - 3 } & Easy to access & Low Priority \\
\cline { 2 - 3 } & Flexible & Concentrate Here \\
\cline { 2 - 3 } & Fast at work & Keep up the Good Work \\
\hline
\end{tabular}


Thus, it can be said that the creation of digital culture by providing trust and empowering employees with technology follows changes and balances between workers and management by making clear and directed work plans related to organizational goals, making digital culture a competitive advantage in supporting employee performance, cultural change by trusting employees empowering them to use technology as the balance between workers and management changes.

Table 7 - The Result of Organizational Learning Variables

\begin{tabular}{|c|c|c|}
\hline Variable & Aspect & Result \\
\hline \multirow{4}{*}{ Organizational Learning } & Developing Ability & Possible Over Skill \\
\hline & Develop skills & Concentrate Here \\
\hline & Learn to see the whole together & Keep up the Good Work \\
\hline & Developing sustainable capacity & Keep up the Good Work \\
\hline
\end{tabular}

Thus, it can be said that organizational learning can assist leaders and employees in dealing with learning challenges by providing them with the tools to pursue a creative vision of learning and to work together effectively and adapt to change.

Table 8 - The Result of the Innovation variable

\begin{tabular}{ccc}
\hline Variable & \multicolumn{1}{c}{ Aspect } & Result \\
\hline \multirow{3}{*}{ Innovation } & Value creation using knowledge & Low Priority \\
\cline { 2 - 3 } & Relevant resource value creation & Low Priority \\
\cline { 2 - 3 } & Enterprise adaptive value search & Concentrate Here \\
\cline { 2 - 3 } & Developing a national network & Concentrate Here \\
\cline { 2 - 3 } & Develop international network & Keep up the Good Work \\
\hline
\end{tabular}

Thus, it can be said that innovation can create the role of the company in providing motivation and encouraging employees to create new ideas, motivation can be seen directly from the character of employees who are naturally enthusiastic and happy in carrying out their work-related tasks to create products and services that provide a competitive advantage.

\section{CONCLUSION}

The analysis test results show that the digital leadership variable has no significant effect on employee performance. This means that if Digital leadership does not characterize as visionary leadership, is good at speaking, cannot convince and give confidence to others, and lacks motivation for employees in achieving employee performance goals.

The analysis test results show that the digital leadership variable has a direct effect on innovation. This means that the role of influential digital leadership is very important in trying new technologies by being flexible and adaptable, facilitating employee innovation needs in improving employee performance.

The analysis test results show that Digital Culture Variables on employee performance through innovation has no effect, which means that the main obstacle in digital transformation is the lack of support from superiors by changing their style from top-down decision-makers to coaches having a strong vision of opportunities and experience by increasing credibility in the eyes employees, Lack of interaction and collaboration by creating an organized cross-functional team in carrying out the project from start to finish.

\section{CONFLICT OFTERESTS}

The authors declared no potential conflicts of interest concerning the research, authorship, and/or publication of this article.

\section{ACKNOWLEDGMENTS}

The authors greatly acknowledge the support from the Universitas Negeri Jakarta, Indonesia for providing the necessary resources to carry out this research work. The authors 
are also grateful to the anonymous reviewers and journal editorial board for their many insightful comments, which have significantly improved this article.

\section{REFERENCES}

1. Abbas, N., \& Nawaz, A. (2019). What followers are saying about transformational leaders fostering employee innovation via organizational learning, knowledge sharing, and social media use in public organizations? Government Information Quarterly, (July), 101391. https://doi.org/10.1016/j.giq.2019.07.003.

2. Bowen, T., \& Pennaforte, A. (2017). The impact of digital communication technologies \& new remote-working cultures on the socialization and work-readiness of individuals in wil programs. International Perspectives on Education and Society. https://doi.org/10.1108/S1479-3679201700000032006.

3. Durou, E., Abou Jaoude, J., \& Khalife, R. (2016). The changing role of people management in the digital age. Deloitte \& Touche (ME), 1-7. https://doi.org/10.1021/bk2018-1274.ch008.

4. Farooqui, MS, \& Nagendra, A. (2014). The Impact of Person Organization Fit on Job Satisfaction and Performance of the Employees. Procedia Economics and Finance, 11(14), 122-129. https://doi.org/10.1016/S2212-5671(14)00182-8.

5. Freitas, R. de C., Freitas, M. do CD, Gomes de Menezes, G., \& Odorczyk, RS (2018). Lean Office contributions to organizational learning. Journal of Organizational Change Management, 31(5), 1027-1039. https://doi.org/10.1108/ JOCM-06-2017-0221.

6. Idris, S., \& Kuala, U. (2020). The effect of organization learning role conflict and organizational culture on employee performance and organizational performance. International Journal of Business Management and Economic Review, 3(01), 111-119.

7. Jennifer Buchanan, et al. (2016). How digital technologies are changing the workforce and how enterprises can adapt and evolve. Digital Workplace and Culture, 7.

8. Maktabi, SH, \& Khazaei, A. (2014). The Impact of Organizational Learning on Organizational Performance and Organizational Innovation: Evidence from Bank Industry of Iran. International Journal of Economy, Management and Social Sciences, 3(10), 569573.

9. Maroofi, F., \& Kahrarian, F. (2015). Organizational learning and Innovation: Organizational learning. Handbook of Research on Entrepreneurship in the Contemporary Knowledge-Based Global Economy. https://doi.org/10.4018/978-1-46668798-1.ch007.

10. Nunzio Casalino1, Marisa Ciarlo2, at all. (2017). An Innovative Managerial Model for the Digital Culture. International Journal of Engineering Pedagogy (IJEP), 3(S4), 31. https://doi.org/10.3991/ijep.v3is4.3450.

11. Osman, S., Shariff, SH, \& Lajin, MNA (2016). Does Innovation Contribute to Employee Performance? Procedia - Social and Behavioral Sciences, 219, 571-579. https://doi.org/10.1016/j.sbspro.2016.05.036.

12. Rahmawati, A. (2020). The Influence of Digital Culture on Employee Performance at the Telkom Education Foundation (Case Study of the Ypt Activity Implementing Agency). Journal of Management and Business Review, 16(2), 129-148. https://doi.org/ 10.34149/jmbr.v16i2.153.

13. Stone, SM (2019). Digitally Deaf Why Organizations Struggle with Digital Transformation. Springer Nature Switzerland AG 2019. https://doi.org/10.1007/978-3-030-01833-7.

14. Tabrizi, B., Lam, E., Girard, K., \& Irvin, V. (2019). Digital Transformation Is Not About Technology. Harvard Business Review, 2-7. Retrieved from https://hbr.org/2019/03/digital-transformation-is-not-about-technology.

15. Taherdoost, H. (2018). Validity and Reliability of the Research Instrument; How to Test the Validation of a Questionnaire/Survey in a Research. SSRN Electronic Journal, (September). https://doi.org/10.2139/ssrn.3205040.

16. Telkom. (2018). Telkom Indonesia 2018 annual report, Stronger for your digital experience (p. 17). 
17. Temelkova, (2018). Skills for Digital Leadership - Prerequisite for Developing High-Tech Economy. International Journal "Information Theories and Applications, 25(4), 50-74.

18. Uzelac, A., \& Relations, I. (2015). Digital culture the changing dynamics. Digital Culture the Changing Dynamics, 12(January 2008), 213.

19. Varadarajan, R. (2018). Innovation, Innovation Strategy, and Strategic Innovation. Innovation and Strategy, 15, 143-166. https://doi.org/10.1108/s1548643520180000015007.

20. Yu, Y., Dong, XY, Shen, KN, Khalifa, M., \& Hao, JX (2013). Strategies, technologies, and organizational learning for developing organizational innovativeness in emerging economies. Journal of Business Research, 66(12), 2507-2514. https://doi.org/10.1016/j.jbusres.2013.05.042.

21. Zehir, C., \& Wujiabudula, A. (2016). the Effects of Organizational Learning on Firm Performance Through Product Innovation. Journal of Global Strategic Management, 1(10), 79-79. https://doi.org/10.20460/jgsm.20161022388.

22. Zhong, L. (2017). Indicators of Digital Leadership in the Context of K-12 Education. Journal of Educational Technology Development and Exchange (JETDE), 10(1), 3. 